\title{
Assessment and monitoring of soil quality using near infrared reflectance spectroscopy (NIRS)
}

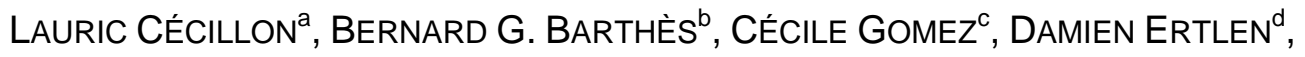

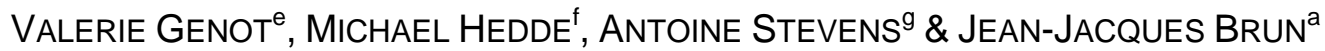

- Review paper -

Addresses:

${ }^{a}$ Cemagref Grenoble, Mountain Ecosystems Research Unit, 2 rue de la Papeterie, BP 76, 38402 Saint Martin d'Hères, France

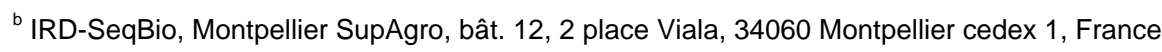

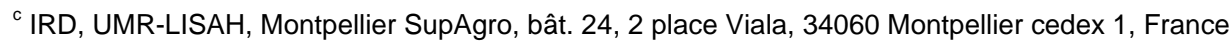

${ }^{\text {d } C N R S ~ / ~ U n i v e r s i t e ́ ~ L o u i s ~ P a s t e u r, ~ L a b o r a t o i r e ~ I m a g e ~ e t ~ V i l l e, ~} 3$ rue de l'Argonne, 67000 Strasbourg, France

${ }^{\mathrm{e}}$ Gembloux Agricultural University (FUSAGx) - Soil-Ecology-Land Development Department - Laboratory of Soil science, Belgium

${ }^{\dagger}$ INRA, UR 251 PESSAC, RD 10, 78026 Versailles, France

${ }^{9}$ Département de Géographie, Université catholique de Louvain, 3 place Pasteur, 1348 Louvain-La-Neuve, Belgique

Correspondence: L. Cécillon, Phone: + 33 (0)130 799 564, E-mail: cecillon@cetiom.fr, Webpage: http://lauric.cecillon.free.fr/ 


\section{Summary}

Soil degradation processes have dramatically increased in their extent and intensity over the last decades. Progressively, actions have been taken in order to evaluate and reduce the major threats that have already wreaked havoc on soil conditions. Efficient and standardized monitoring of soil conditions is thus required but soil quality research is facing an important technological challenge because of the number of properties involved in soil quality. The objective of the present review is to examine critically the suitability of near infrared reflectance spectroscopy (NIRS) as a tool for soil quality assessment. We first detail the soil quality-related parameters (chemical, physical and biological) that can be predicted with NIRS through laboratory measurements. The ability of imaging NIRS (airborne or satellite) for mapping a minimum data set of soil quality is also discussed. Then we review the most recent research using soil reflectance spectra as an integrated measure of soil quality, from global site classification to the prediction of specific soil quality indices. We conclude that imaging NIRS enables the direct mapping of some soil properties and soil threats, but that further developments to solve several technological limitations identified are needed before it can be used for soil quality assessment. The robustness of laboratory NIRS for soil quality assessment allows its implementation in soil monitoring networks. However, its routine use requires the development of international soil spectral libraries that should become a priority for soil quality research. 


\section{Résumé}

Les processus de dégradation des sols ont fortement augmenté au cours des dernières décennies. Des mesures sont progressivement mises en place afin d'évaluer et de limiter l'impact des principales menaces qui ont déjà provoqué une diminution préoccupante de la qualité des sols. Des méthodes efficaces et standardisées de suivi de la qualité des sols sont donc indispensables, mais les nombreuses propriétés impliquées dans la qualité des sols compliquent son évaluation rigoureuse. L'objectif de cette revue est d'examiner le potentiel de la spectroscopie proche infrarouge (SPIR) comme outil rapide de caractérisation de la qualité des sols. Nous dressons d'abord l'inventaire des propriétés du sol liées à sa qualité qui sont prédictibles par des mesures SPIR en laboratoire. Le potentiel de l'imagerie embarquée SPIR (satellite, avion) est également abordé. Nous réalisons ensuite une synthèse des applications utilisant la réflectance spectrale des sols comme mesure intégrée de leur qualité, depuis la classification de sites selon leur état de dégradation jusqu'à la prédiction d'indices spécifiques de qualité du sol. Nous concluons que l'imagerie SPIR permet de cartographier quelques propriétés et menaces pesant sur les sols, mais les limites technologiques relevées exigent d'importants développements pour en faire un outil robuste d'évaluation de la qualité des sols. La fiabilité de la technique SPIR par mesures en laboratoire permet sa mise en œuvre rapide dans les réseaux de mesures de la qualité des sols. Toutefois, son utilisation en routine nécessitera le développement de librairies spectrales internationales, qui devrait constituer une des priorités de recherche sur la qualité des sols. 


\section{Introduction}

In a technology-governed and energy-intensive world, degradation of soil conditions has become a widespread problem with negative consequences for both agricultural, natural ecosystems and urban areas (Wander \& Drinkwater, 2000; Biasioli et al., 2005). Scientific and political awareness of soil has emerged progressively during the second part of the 20th century (Breure, 2004), with concerns over the sustainability of agriculture and the increasing number of contamination incidents (Eijsackers, 2004). Soil scientists started attempting to define soil quality (Larson \& Pierce, 1991) and the first soil protection policy appeared in the 1970s (Eijsackers, 2004), although the concept of soil quality is still debated (Sojka \& Upchurch, 1999). Nowadays, quality or vitality of soils is considered to be their long-term ability to maintain their functions, which can be summarized by a combination of different elements: Robustness, Resilience, Recovery, and structural and functional Richness (Eijsackers, 2004). Another important feature in the definition of soil quality is its positive interaction with the external environment (Larson \& Pierce, 1991), which is often described as the many ecosystem services provided by soils to human life (Lavelle et al., 2006).

Practical assessment of soil quality remains a challenging task since it requires the integrated consideration of key soil properties involved in soil functioning and their variation in space and time (Doran \& Parkin, 1994; Doelman \& Eijsackers, 2004). Soil monitoring is thus essential for the early detection of changes in soil quality (Morvan et al., 2008). However, selecting monitoring variables remains difficult (Zornoza et al., 2007) as the establishment of any a priori criterion and threshold for soil quality can be considered subjective since it relies on expert opinions (Sojka \& Upchurch, 1999; Andrews et al., 2004; Velasquez et al., 2007).

Recent studies have proposed several conceptual frameworks for monitoring soil quality (Andrews et al., 2004; Velasquez et al., 2007). They usually share a common first step with the choice of a minimum data set (MDS, Table 1) made of chemical, physical, and biological properties essential in terms of soil functioning (Doran \& Safley, 1997). Then soil attributes are selected from 
the MDS for their suitability to assess a particular soil function (Andrews et al., 2004), a specific soil ecosystem service (Velasquez et al., 2007), or a key threat to soils (Morvan et al., 2008). Each indicator measure is further normalized to a unitless score, and finally integrated into a global soil quality index value (Andrews et al., 2004; Velasquez et al., 2007), fulfilling Haberern's wish (1992). However, since many soil analyses are involved, monitoring such soil quality indices at the regional or global scale remains too expensive and time consuming when using standard procedures for the measurement of soil properties. This statement is particularly true when considering the five- to ten-year sampling interval required by soil monitoring networks (SMN; Jolivet et al., 2006) for an early detection of changes in soil quality, in order to implement policy measures to protect soils and maintain their sustainable use (Morvan et al., 2008).

By contrast, near infrared reflectance spectroscopy (NIRS) is a rapid, non-destructive, reproducible and cost-effective analytical method involving diffuse reflectance measurement in the near infrared region (NIR; 780-2500 nm; Sheppard et al., 1985). Reflectance signals result from vibrations in $\mathrm{C}-\mathrm{H}, \mathrm{O}-\mathrm{H}, \mathrm{N}-\mathrm{H}$ chemical bonds, and provide information about the proportion of each element in the analysed sample (Ciurczack, 2001). Absorbances in the NIR are weak since they concern overtones or combinations of fundamentals (Figure 1; Wetzel, 1983). Although a qualitative interpretation of NIR spectra through visual analysis can be achieved (Stoner \& Baumgardner, 1981), direct quantitative prediction of soil characteristics is almost impossible because soil constituents interact in a complex way to produce a given spectrum. The quantification of the property of interest is therefore usually done with statistical models and is the subject of the discipline called Chemometrics. An overview of the use of chemometrics in spectroscopy, its history and main concepts has been published by Geladi (2003). The quantitative analysis of NIRS data may be conducted in two ways, both requiring the implementation of multivariate statistics (Burns \& Ciurczack, 2001). Firstly, clustering techniques can be used to discriminate samples or to detect changes in sample properties (Albrecht et al., 2008). Secondly, a set of regression methods allows the prediction of many properties of unknown samples using calibration equations that relate spectral information to sample properties measured by conventional methods, within a calibration subset (Martens \& Dardenne, 1998; Chang et al., 2001). 
Near infrared analysis is a well-known tool that has been utilized in many disciplines such as food science and pharmacology. Although its potential has been recognized by soil scientists for a few decades (Bowers \& Hanks, 1965; Stoner \& Baumgardner, 1981; Dalal \& Henry, 1986), the use of NIRS for soil applications remains poorly developed (Ben-Dor et al., 2008a). Nevertheless, the appearance of portable and flexible NIR devices could provide the large amount of spatial data required for monitoring soil conditions or modelling soil processes.

One can basically distinguish three types of NIRS measurements for soils (although other classifications are possible): (i) laboratory measurements, (ii) proximal sensing measurements and (iii) remote sensing measurements. The two latter techniques are able to collect spectral data insitu and are therefore usually exploited to map soil properties (Barnes et al., 2003). Many authors report the development of spectral sensors mounted on tractors (Shonk et al., 1991; Sudduth \& Hummel, 1993; Mouazen et al., 2007). These systems are generally used in precision agriculture to manage the quantity of nutrient inputs into soils (Adamchuk et al., 2004). Proximal sensing may also include hand-held measurement, which is used as a fast tool to monitor soil properties in-situ (Kooistra et al., 2001; Udelhoven et al., 2003; Stevens et al., 2008). Ben-Dor et al. (2008b) recently presented a NIR sensing device able to collect in-situ 3D spectral data through an entire soil profile, allowing a rapid and objective soil classification. Remote sensing of soil properties has been attempted using aerial photographs (e.g. Chen et al., 2000), multispectral (e.g. Galvão et al., 2001) or hyperspectral images (also called imaging spectroscopy; e.g. Ben-Dor et al., 2002). Imaging spectroscopy differs from multispectral imaging in its greater number of wavebands, enabling precise recording of the spectrum and a detailed analysis of spectral properties of the soil surface.

The aim of this paper is to review the most recent applications of NIRS for soil quality assessment in order to examine critically the suitability of its implementation as a tool in soil monitoring plans and networks. First, we present laboratory and imaging NIR spectrometry as tools for the quantification and mapping of many MDS variables for soil quality assessment. Then we give a brief review of studies using NIRS as an integrated measure of soil quality. These range 
from global site classification to the prediction of specific soil quality indices designed to assess particular soil ecosystem services or functions. Finally we review the main research needs that could allow the implementation of laboratory NIRS for the routine assessment of soil conditions in SMN, and develop the use of imaging NIRS for the regional monitoring of soil quality.

\section{Monitoring MDS of soil quality with NIRS}

MDS information within NIR spectra of soils: insights from laboratory spectrometry

An increasing number of studies emphasise the ability of NIR analysis for the prediction of many soil attributes, including chemical, physical, and biological properties (Reeves et al., 2000; Malley et al., 2004; Viscarra-Rossel et al., 2006). Some of these variables are key properties which were included in the first MDS for soil quality assessment published at the beginning of the 1990s (Larson \& Pierce, 1991; Doran \& Parkin, 1994). Since a consensus is still to be found on a MDS for soil quality, we give a list of soil chemical (Table 1a), physical (Table 1b), and biological (Table 1c) properties included in published MDS along with the predictive efficiency of NIR analysis for these properties. Most NIR regression models presented in Table 1 are based on laboratory measurements under controlled conditions, which avoid disturbing factors characterizing field measurements like soil moisture content, soil roughness and vegetation cover (Stevens et al., 2008). When available, we also provide the NIR wavelengths or spectral intervals closely associated to these MDS variables of soil quality.

Regarding soil chemical properties (Table 1a), numerous authors have reported accurate NIRS predictions of soil total C and N (Al-Abbas et al., 1972; Chang et al., 2001; Brunet et al., 2007) and pH (Chang et al., 2001; Reeves \& McCarty, 2001; Shepherd \& Walsh, 2002). This is consistent, considering that numerous bonds between $\mathrm{C}$ and $\mathrm{O}, \mathrm{N}$ or $\mathrm{H}$ absorb light in the NIR region, while $\mathrm{pH}$ prediction has been attributed to $\mathrm{O}-\mathrm{H}$ groups (Malley et al., 2004). Good 
predictions for $\mathrm{K}$ have also been achieved using NIRS (Chang et al., 2001; Confalonieri et al., 2001; Shepherd \& Walsh, 2002) though Malley et al. (2004) considered it was generally not amenable to NIRS analysis. Good NIRS predictions are less frequent for soil P and mineral N as underlined by Malley et al. (2004): calibrations for $\mathrm{P}$ and mineral $\mathrm{N}$ rarely perform well in soil $\left(\mathrm{R}^{2}=\right.$ 0.4-0.5 in general; Malley et al., 2002, for P and mineral N; Chang et al., 2001, and Shepherd \& Walsh, 2002, for P), though good results have sometimes been obtained (Confalonieri et al., 2001, and Bogrekci \& Lee, 2005, for P; Cho et al., 1998, for mineral N). Contradictory NIRS predictions have been reported for salt content in soil $\left(\mathrm{R}^{2}=\right.$ 0.1-0.6 for Chang et al., 2001, and Malley et al., 2002; $\mathrm{R}^{2}=$ 0.1-0.8 for Farifteh et al., 2008; but $\mathrm{R}^{2}=$ 0.7-0.8 for Dunn et al., 2002) and for electrical conductivity $\left(\mathrm{R}^{2}=\right.$ 0.4-0.6 for Dunn et al., 2002; but $\mathrm{R}^{2}=0.7$ for Malley et al., 2004). Very contradictory results have been reported regarding NIRS prediction of soil heavy metal content depending on the element, and apparently, on the site and on the reference method too. For instance, some authors reported good predictions of Cd, Co and Zn (Kooistra et al., 2001, Wu et al., 2007, and Kooistra et al., 2001, respectively) while others reported poor predictions (Wu et al., 2007, Malley et al., 2004, and Chang et al., 2001, respectively). Contradictory results have also been achieved for $\mathrm{Cr}, \mathrm{Cu}, \mathrm{Ni}$ and $\mathrm{Pb}$ (Malley et al., 2004; Wu et al., 2007). Similarly, the fate of organic pollutants in soil is an important and widespread concern, although these are not currently included in MDS of soil quality. Bengtsson et al. (2007) reported promising results regarding NIRS prediction of pesticide sorption to soils. Contradictory results for $\mathrm{K}, \mathrm{P}$, mineral $\mathrm{N}$, salt or heavy metals may have several causes, either relating to the reference methods (e.g. prediction of extractable cations varies with the extraction method; Chang et al., 2001), the nature of the studied element (e.g. spectrally distinct P-containing compounds may variably contribute to soil P content; Malley et al., 2004), its concentration (e.g. below detection limits), or possible interactions with other components (e.g. water, organic matter or iron oxides; Malley et al., 2004). To a larger extent, poor predictions may also result from low-quality reference data, subsampling errors (reference and spectral analyses being performed on dissimilar subsamples), heterogeneity of sample sets (optimal calibration requires limited but sufficient set heterogeneity), or inappropriate calibration (e.g. fail to improve the signal-to-noise ratio or overfitting). 
There have also been attempts to predict soil physical properties using NIRS (Table 1b), which have yielded good results for soil particle size distribution (especially for clay content; Al-Abbas et al., 1972; Ben-Dor \& Banin, 1995a; Chang et al., 2001; Morón \& Cozzolino, 2003), soil moisture (Bowers \& Hanks, 1965; Dalal \& Henry, 1986; Ben-Dor \& Banin, 1995a; Chang et al., 2001), water holding capacity (Sudduth \& Hummel, 1993; Zornoza et al., 2008), infiltration of crusted soils (Goldshleger et al., 2002), and maximum temperatures reached by burned soils (Guerrero et al., 2007), but not for the size distribution of water-stable aggregates (Chang et al., 2001). Particle size effects on light transmission and reflection, and strong absorption features exhibited by water, explain the accurate predictions for texture and moisture, while poor performance regarding aggregate distribution has been attributed to inappropriate procedures (Chang et al., 2001).

NIRS prediction of soil biological properties has often yielded good results (Table 1c), as reported for microbial biomass (Reeves et al., 1999; Chang et al., 2001; Ludwig et al., 2002), soil respiration (Palmborg \& Nordgren, 1993; Chang et al., 2001; Ludwig et al., 2002), potentially mineralizable N (Chang et al., 2001; Fystro, 2002; Ludwig et al., 2002; Shepherd \& Walsh, 2002), and even for the ratio of microbial to total organic C (Ludwig et al., 2002; Cécillon et al., 2008) and for the density of soil microorganisms (Zornoza et al., 2008). Good predictions have been attributed to the similarity between spectral responses of most biological properties and that of soil organic C (Chang et al., 2001).

Upscaling NIR assessment of soil quality: imaging spectrometry

Imaging spectrometry might yield a new dimension to the field of NIRS for the prediction of soil properties by enlarging the envelope of laboratory spectrometry spatially (Ben-Dor et al., 2008a). This wider spatial dimension can be obtained using visible-NIR (Vis-NIR) spectrometers onboard either airborne or satellite. Remotely-sensed hyperspectral satellite data offer a synoptic view and a repetitive coverage which are two important advantages compared to ground observations and hyperspectral airborne data. While the contribution of multispectral satellite data in the analysis of 
soil properties has been already investigated (e.g. Ben-Dor \& Banin, 1995b; Nanni \& Demattê, 2006), the use of hyperspectral satellite data for soil property prediction remains poorly studied.

Using airborne hyperspectral sensors, fairly good to good NIRS predictions have been achieved for soil organic $C\left(R^{2}=0.74-0.9\right.$, Ben-Dor et al., 2002; Selige et al., 2006; Stevens et al., 2008; De Tar et al., 2008; Patzold et al., 2008), total $N\left(R^{2}=0.92\right.$, Selige et al., 2006), clay content $\left(\mathrm{R}^{2}=\right.$ 0.61-071, Selige et al., 2006; De Tar et al., 2008; Lagacherie et al., 2008), sand or silt content $\left(R^{2}=0.75-0.95\right.$, Selige et al., 2006; De Tar et al., 2008), soil moisture $\left(R^{2}=0.64\right.$, Ben-Dor et al., 2002), Cation Exchange Capacity $\left(R^{2}=0.66-0.67\right.$, Ben-Dor et al., 2002; De Tar et al., 2008), $\mathrm{pH}\left(\mathrm{R}^{2}=0.52-0.61\right.$, Ben-Dor et al., 2002; De Tar et al., 2008) and $\mathrm{Ca}, \mathrm{Mg}, \mathrm{Na}, \mathrm{Cl}, \mathrm{K}, \mathrm{P}\left(\mathrm{R}^{2}=0.58-\right.$ 0.7, De Tar et al., 2008).

Weng et al. (2008), obtained good predictive models for soil salt content in the Yellow river delta using the Hyperion satellite hyperspectral sensor $\left(R^{2}=0.78\right)$. By contrast, relatively low prediction accuracy was reported for soil organic $C$ with the same sensor $\left(R^{2}=0.51\right.$, Gomez et al., 2008). This lower accuracy was assumed to be the result of several factors: (i) the low signal-tonoise ratio of Hyperion spectra, (ii) the low spatial resolution (30 m) which induces mixing problems, and (iii) the relatively low level of carbon in the soils.

Despite the potential of imaging spectrometry for mapping soil properties within the MDS, there are still several limitations, which may preclude the use of such technique to address real problems. These limitations can be related to: (i) the measure itself (sensing device and measuring environment), and (ii) differences in sample preparation and conditions which cannot be controlled in the field.

The first category of limitations is caused by the distance between the sensor and the soil surface. Appropriate correction techniques are required to handle the effects of varying light and atmospheric conditions on the signal. A precise georeferencing of the image is also needed to attribute correctly each soil sample to a pixel. A good introduction to the processing and geometric/atmospheric correction of hyperspectral data can be found in Aspinall et al. (2002). BenDor et al. (2004) examined the accuracy of several correction methods to retrieve the true 
reflectance values from imaging spectroscopy data. They found a difference of up to $40 \%$ between modelled and true reflectance information at specific wavelengths, depending on the correction method used and variability in atmospheric conditions. When using a 'top-down' approach (i.e. detection of a given soil property based on field sampling) and when the spatial extent of hyperspectral images is small, atmospheric effects may be constant over the study area and a particular object will appear similar across the image (Aspinall et al., 2002). However, when the analysis is conducted over larger images or when a 'bottom-up' approach is used (i.e. detection of a given soil property based on laboratory-based spectral libraries), accurate atmospheric correction is crucial. Another limitation is the relatively low signal-to-noise ratio of hyperspectral data compared with laboratory data due to a low integration-time over the target area. Chabrillat et al. (2002) demonstrated for instance that the detection of expanding clays may be degraded because the spectral feature used to identify the type of clay may be of the same amplitude as the noise in the data. By comparing airborne hyperspectral HyMap and AVIRIS data over the same area, Chabrillat et al. (2002) also showed the influence of the spectral and spatial configuration of the sensor. The coarser spectral resolution of HyMap compared to AVIRIS in the 2000-2500 nm spectral region masked partly the doublet spectral feature at $\sim 2150 \mathrm{~nm}$ related to clay type and reduced the effectiveness of the classification. Conversely, the higher spatial resolution of HyMap allowed obtaining purer spectral end-members (i.e. spectra not influenced by other soil constituents or by soil surface characteristics) in more heterogeneous sites. Spatial resolution is thus a matter of importance when the studied soil property occurs in a patchy way or is affected by a strong spatial variability (e.g. soil crusting).

The second category of limitations is related to the spatial and temporal variability of soil surface conditions. This variability often reduces the accuracy of the prediction of soil properties by chemometric techniques in areas having different surface conditions than the ones in the calibration set (Stevens et al., 2008). Some of the properties that are subject to variation in time and space are: moisture content, degree of soil crusting, particle-size, soil roughness, vegetation or crop residue cover. In the study of Kooistra et al. (2003), soil moisture and vegetation cover were identified as the main causes of the loss of accuracy between field and laboratory spectra. 
The effects of soil roughness on bidirectional reflectance behaviour have been studied in detail (see e.g. Cierniewski \& Courault, 1993). Usually, rough soils present highest reflectance values when measured from the direction of the illumination source and lower reflectance values in positions away from this peak. Since remote sensors record the soil surface under varying illumination and viewing angles, this phenomenon induces a spectral variability not specifically related to the studied property. Another constraint of importance is the vegetation/residue cover, partly masking the soil signal. Bartholomeus et al. (2007) showed that even a small vegetation cover $(5 \%)$ leads to large variations in the estimations of soil parameters. Imaging spectrometry campaigns must therefore be organized only in arid/semi-arid regions or when the soil has been recently tilled. Finally, imaging spectroscopy is only able to measure the reflectance within the first few millimetres of the surface and can therefore not predict a given property for the entire soil profile. As a consequence, such a method of data acquisition may be of little interest when strong vertical gradients in soil properties occur.

An alternative solution: the rough quantification of MDS variables

As presented above, NIR spectra of soil samples contain much information relevant to soil quality, and multivariate regressions of NIR spectra from laboratory and imaging spectrometry can accurately predict several properties of MDS. However, soil quality does not always need to be precisely quantified. Many industrial or agricultural applications only require a classification of soil condition with respect to a critical test value for key properties. Shepherd \& Walsh (2002) were the first to propose the use of laboratory NIR analysis for the discrimination of soils falling above or below specific cut-off values for most properties related to soil fertility. They showed that soil samples could be roughly discriminated using classification trees even for properties like exchangeable $\mathrm{K}$ and extractable $\mathrm{P}$ which are poorly predicted by regression models. These promising findings were further confirmed by Cohen et al. (2005a) on an extensive data set of quality parameters for wetland soils, including soil microbiological attributes. 


\section{Integrated assessment of soil quality with NIR analysis}

\section{NIRS as a fingerprint of global soil conditions}

Since NIR spectra of soils reflects a set of soil quality attributes like organic matter content and some chemical and biological properties, some researchers have hypothesized that laboratory NIRS could probably be used to discriminate clusters of soil samples differing in their "global" quality. Velasquez et al. (2005) first tested the use of principal component analysis (PCA) and discriminant analysis to separate soils from different land uses. This strategy successfully discriminated clusters of sites depending on land-use type, and co-inertia analyses revealed significant relationships between NIR spectra and various physico-chemical properties of soil samples. The authors also identified NIR wavelength intervals characteristic of the soil-use systems. This PCA strategy was further applied by Cécillon et al. (2009) on a NIR spectral data set of Mediterranean topsoils and earthworm casts collected in areas affected by wildfire (Figure 1). Soil samples and biogenic structures were well separated by PCA on NIR spectra, depicting the influence of earthworms on soil quality, as previously demonstrated by Hedde et al. (2005). Furthermore, a strong effect of wildfire on NIR spectra could also be identified in this PCA. This striking result was the first illustration of the use of laboratory NIRS to estimate the effect of an ecological factor (wildfire) on soil conditions. Odlare et al. (2005) coupled PCA of NIR soil spectra and geostatistics to map spatial variation of soil properties. Since principal components of PCA synthesize information on global soil condition, such an approach is interesting for mapping soil quality in precision farming, or for the quantitative spatial assessment of polluted areas in environmental remediation procedures.

Other studies have focussed on the use of laboratory NIR analysis as an integrated tool for the assessment of global soil quality. Using a holistic definition of soil quality, Vågen et al. (2006) aggregated ten commonly used agronomic indicators of soil quality $(\mathrm{pH}$, organic $\mathrm{C}$, total $\mathrm{N}, \mathrm{P}, \mathrm{Ca}$, Mg, K, CEC, clay, silt) and developed ordinal soil condition classes (poor, average, good), which 
were used to identify spectral wavebands that could diagnose soil condition. They found that five wavelengths were related to their soil quality index: relative reflectance at 570, 1410, 2040 and $2390 \mathrm{~nm}$ were negatively correlated with soil condition class whereas relative reflectance at 1940 $\mathrm{nm}$ (which is almost certainly due to $\mathrm{O}-\mathrm{H}$ bond of water) was positively correlated with soil condition class. The authors computed a soil fertility index (SFI), calibrating the membership of the three soil condition classes to reflectance spectra of soils using a proportional odds ordinal logistic regression model. Finally, the SFI was successfully applied to the spatial representation of global soil quality based on remote sensing satellite imagery. Awiti et al. (2008) applied the same proportional odds ordinal logistic regression modelling technique to chronosequence classes of forest-cropland plots and the 10 first principal components calculated from PCA of soil NIR spectra. Using this strategy, the authors could determine three global soil condition classes (good, average and poor) which were then used for the successful classification of soils from unknown sites. Cohen et al. (2006) used another NIR-based approach of global soil quality. They combined ordinal logistic regression and classification trees of soil NIR spectra to discriminate between ecological condition categories. Using classification trees, they identified key spectral regions for ecological condition classification: 2200-2300 nm, 1100-1200 nm, and 500-600 nm. They concluded that site classification with soil reflectance data was more efficient than with biogeochemical data, especially for the discrimination of severely degraded sites. Soil NIR spectra thus provide an effective tool for rapid condition diagnosis of soils and ecosystems (Cohen et al., 2006).

NIR-based diagnostics of specific soil quality

Global assessment of soil conditions with NIRS, as presented above, enables a rapid tracking of states of soil quality or of its changes after a disturbance. In addition, successful classifications of sites have been built regarding land-use type or global soil condition classes. However, soil quality policies usually address specific management goals such as productivity, waste recycling or 
environmental protection (Andrews et al., 2004). Thus, methodologies for soil quality assessment should be able to measure specific soil functions or soil ecosystem services associated with these management goals. Recently, the European Commission (2006) identified several key threats to European soils, including soil erosion, soil contamination and loss of organic matter. An important objective of soil quality research is thus to provide economically realistic tools for the monitoring of these threats (Morvan et al., 2008).

Following the widespread use of remote sensing in environmental management, the suitability of imaging spectrometry for specific soil quality assessment has been tested since the 1990 s and was recently reviewed by Ben-Dor et al. (2008a, see references therein). The authors listed promising results of imaging NIRS regarding the quantification and mapping of some specific soil threats. Salinisation of soils has been fairly extensively studied using airborne reflectance data (HyMap, DAIS-7915). Qualitative indicators of soil erosion have also been mapped using airborne AVIRIS imaging spectrometry, with an accuracy of about $80 \%$, which was superior to that achieved using Landsat-TM imagery. HyMap airborne data have been used to estimate the distribution of sludge containing large concentrations of heavy metals, demonstrating the potential of NIRS imaging to map soil contamination and monitor environmental remediation procedures. Finally, airborne reflectance data (AVIRIS, HyMap) in the presence of significant vegetation cover and NIRS satellite imaging (ASTER, wavebands between 2145 and $2430 \mathrm{~mm}$ ) have been shown reliable for mapping soil swelling. These results could be useful to engineers for construction planning, decision makers for better management of the environment, and farmers in allocating hazardous areas like floods and erosion sites (Ben-Dor et al., 2008a).

The application of laboratory spectrometry for the specific assessment of soil quality started in the 2000s. Cohen et al. (2005b) presented the first application for the rough assessment of a specific soil threat. They showed that NIRS clearly outperformed a frequently used empirical model for classifying sites according to soil erosion status. They used classification trees to provide an objective definition of degraded and intact soil conditions and developed NIRS-based screening models calibrated with reliable visual observations of degraded sites. These NIRS classification models were found efficient in discriminating three degradation classes (intact, moderate and 
severe erosion). This rough assessment of a soil threat could be a useful tool for characterizing site conditions prior to irreversible degradation (Cohen et al., 2005b).

However, an important goal for soil monitoring is the detection of small changes in specific key threats, functions or services over space and time. Thus, most recent soil quality indicators have been designed to achieve these ends (Andrews et al., 2004; Velasquez et al., 2007), but their implementation in soil monitoring networks remains too expensive and time consuming to be economically realistic using conventional soil analyses.

Recent research has focussed on the quantitative prediction of specific and targeted soil quality indices with laboratory NIRS. Shepherd \& Walsh (2007) presented some preliminary tests of indices designed to assess particular soil functions or threats such as soil fertility, soil erosion rate, soil erodibility, soil infiltration capacity, and plant growth potential. Their specific spectral indicators were based on the Mahalanobis distance in the principal component space built using a library of soil reflectance spectra. Cécillon et al. (2009) recently proposed a tentative approach based on the direct prediction of specific soil quality indices related to soil ecosystem services using laboratory NIRS. The accuracy of three soil quality indicators derived from the general indicator of soil quality (GISQ; Velasquez et al. 2007) was tested on the impact of wildfire disturbance (time since last fire) and soil engineering activity of earthworms (topsoil versus casts samples). For each sample, conventional analyses related to three soil ecosystem services were performed. Organic matter storage was assessed through organic $\mathrm{C}$ and total and mineral $\mathrm{N}$ contents, nutrient supply through $\mathrm{pH}$ and exchangeable cations ( $\mathrm{Ca}, \mathrm{Mg}, \mathrm{K}, \mathrm{Na}, \mathrm{CEC}$ ), and biological activity through a set of microbiological parameters (microbial $\mathrm{C}$, two extracellular enzymes, potential denitrification and microbial $\mathrm{C}$ to organic $\mathrm{C}$ ratio). Three specific indicators (SI) of soil quality, reflecting the provision of these soil ecosystem services, were then computed using the GISQ approach (Velasquez et al., 2007). Higher SI values indicate more ecosystem services produced, thereby an improved soil quality (Velasquez et al., 2007). The predictive ability of NIR analysis for the three SI was assessed with partial least squares regression (PLSR; Tenenhaus, 1998). PLSR models for the three SI reached "reasonable" statistics (Williams, 1993), with crossvalidated coefficients of determination $\left(Q^{2}\right)$ above 0.90 and ratio of performance to deviation (RPD) 
above 2.8 (Figure 2; Cécillon et al., 2009). These results are the first attempt to predict specific soil quality indices with laboratory NIRS. They open a new pathway for soil quality research, as a simple scan of a soil sample with a NIR spectrometer can provide quantitative information on the provision of a given soil ecosystem service. The same strategy could probably be applied for the assessment of a soil function or a soil threat critical for management goals.

Implementing this cost-effective strategy could have wide implications for the spatial coverage and the sampling frequency of soil monitoring networks (SMN). Existing SMN sites and data could be used for the regional calibration of soil quality indices. Then a quantitative assessment of soil quality could be performed at the field scale depending on the end-user or land manager's needs. The sampling frequency of SMN could also be increased enabling a seasonal assessment of soil quality, which is crucial for the early detection of changes in soil conditions.

\section{Research needs towards NIR monitoring of soil conditions}

Soil spectral libraries: enabling the implementation of laboratory spectrometry in SMN

Hitherto, NIRS has mainly been applied to soils at the field or the landscape scale, and no generalization can be inferred from regression models obtained with such local studies. One of the main gaps in effective monitoring of soil quality with NIRS is the building of NIRS-based regression models capable of assessing soil conditions at the regional scale across various soil types. Shepherd \& Walsh (2002) presented a new approach allowing the regional quantification of many soil properties with laboratory spectrometry. They proposed the use of soil spectral libraries as a tool for building risk-based approaches to soil evaluation. In the spectral library approach, soil properties are measured conventionally for a selection of soils representative of the diversity of the studied region, and then calibrated to soil reflectance spectra. Usually, the size of the calibration sample set is increased until calibrations are found to be sufficiently accurate for user 
requirements. It is then possible to predict the soil properties for new samples that belong to the same population as the library soils. Soils that are poorly described in the library can be further characterized (conventionally) and added to the calibration library (Shepherd \& Walsh, 2002). Brown et al. (2006) applied the soil spectral library strategy using more than $4 \times 10^{3}$ soil samples selected from all 50 US states, two tropical territories and 36 different countries in Africa, Asia, the Americas and Europe. They obtained satisfactory predictive efficiency for various soil physical and chemical properties and concluded that calibrations sufficient for many applications might be obtained with large but obtainable soil spectral libraries $\left(10^{4}-10^{5}\right.$ samples). Genot et al. (2007) worked with a spectral library of ca. $10^{3}$ soil samples representative of the Walloon region (Belgium) and obtained accurate predictions for the soil properties studied (organic $\mathrm{C}$, total $\mathrm{N}$, clay content and CEC). Their work now allows the routine application of laboratory NIRS by the five laboratories providing fertility advice in this region. All applications of soil spectral libraries used advanced multivariate regression techniques to infer soil properties from NIR spectra. Shepherd \& Walsh (2002) and Brown et al. (2006) worked respectively with multivariate adaptive regression splines (MARS), and boosted regression trees (BRT), two non-linear multivariate techniques. Genot et al. (2007) used an improvement of the PLSR algorithm (PLS-Local; Shenk et al., 1997) which matches the sample to be predicted using a small homogeneous group of spectrally similar samples selected from a calibration library. These advanced regression techniques clearly outperformed the classical PLSR approach which is often not on its own an optimal solution for processing soil spectra, especially with large datasets and a wide range of values (Cécillon et al., 2008; Fernández Pierna \& Dardenne, 2008).

All these promising results underline the urgent need to build a universal and standardized soil spectral library. Viscarra Rossel (2008) and colleagues from the International Soil Spectroscopy Group (http://groups.google.com/group/soil-spectroscopy?hl=en) are currently trying to implement such a spectral library for basic soil properties (e.g. organic C, clay content). This huge task sounds feasible for soil chemical properties using existing samples from SMN. When built, it should be possible to compute and monitor some of the specific soil quality indices presented above (e.g. organic matter storage, nutrient supply). However, the current lack of data for many MDS variables 
of soil quality (especially physical and biological properties) could compromise the rapid construction of a universal soil spectral library for the global assessment of soil quality or the specific assessment of soil threats like soil erosion, contamination, or decline in soil biological activity and diversity. The soil spectral library approach for the quantification of soil quality might thus not be successful until the calibration of all MDS variables to soil reflectance spectra has been achieved, which will be difficult.

Furthermore, building NIR spectral libraries for soils raises several problems. The first problem relates to the fact that NIR spectra show subtle variations even when obtained on supposedly identical instruments. This is even more of a problem with spectra from different makes and models of instruments, or those from instruments based on different principles (diode arrays versus Fourier transform or gratings, etc.). The systematic differences between spectra from different instruments can make combining spectra useless for developing calibrations. To overcome these problems, chemometric procedures known as calibration transfer (e.g. Shenk et al., 1985) are used to make spectra from different instruments appear the same. Much research still needs to be done so as to achieve comparability between instruments used for soil spectral measurements. The second related problem is the question of whether the measures of soil attributes included in the spectral libraries, particularly biological measures, obtained at different laboratories, are the same or not. When the two problems are combined, spectral libraries lose much of their value. These problems, while known and discussed greatly in other areas of NIRS (see e.g. Cen \& He, 2007), do not seem to have received much press for soils.

McBratney et al. (2006) proposed an alternative approach that links soil diffuse reflectance spectroscopy with an inference system to predict soil functional properties which are difficult and expensive to measure directly. They measured soil spectra to estimate various basic soil properties which were then used to infer the desired soil functional property via pedotransfer functions. This approach could be promising for the assessment of soil conditions, but reliable pedotransfer functions for global or specific soil quality are not sufficiently developed. 


\section{Challenges for monitoring soil conditions with imaging spectrometry}

Compared to laboratory spectroscopy, imaging spectrometry has, at the present time, some difficulties in producing reliable and robust predictions for routine soil analysis. A large part of the problem is technological (signal-to-noise ratio, spatial and spectral resolution, etc.) or a matter of institutional/scientific will (training of scientists, finding potential end-users) and beyond the scope of this paper (see e.g. Ben-Dor et al., 2008a).

However, some progress can be rapidly achieved by applying more efficient analysis tools. The simplest solution to the problem of spatial variability in soil surface conditions is to record the surface conditions of the soil samples used in the calibration set and restrict the prediction to similar pixels (e.g. based on the Mahalanobis distance). Including a covariant such as soil moisture or roughness in the multivariate regressions is another solution, which requires the measurement of the disturbing factor over the entire study area. The recent convergence of several new measuring technologies aiming to map soil properties (e.g. synthetic aperture radar imagery) enables the investigation of such strategies in the mid-term. As presented above regarding laboratory spectrometry, the stability of the calibrations may also be improved by using more efficient chemometric approaches. For instance, the implementation of the PLS-Local algorithm with hyperspectral data would improve the accuracy, by using samples in the calibration set with surface conditions corresponding to the ones of the pixel to be predicted, providing that the spectral library would represent perfectly all surface conditions in the study area. Marx \& Eilers (2002) have developed a multivariate technique - called penalized signal regressions - that forces the regression coefficients to vary smoothly across wavelengths. It allows the effects of noisy features in the spectral data to be removed from calibrations and yields more robust calibrations in general. Bartholomeus et al. (2008) proposed to use spectral indices (e.g. 1 / [slope 2138-2200 $\mathrm{nm}]$ ), which can be easily related to the biochemical composition of the soil samples and show a greater stability. 


\section{Conclusions}

This review has demonstrated that near infrared reflectance spectra contain much information related to soil quality. Using laboratory NIRS, good predictions can be achieved for many chemical and some physical and biological properties involved in soil conditions. Imaging NIRS can predict some soil chemical properties related to soil quality. Its ability to cover large surfaces in a single flight campaign and thus produce a complete picture of surface soil properties of bare soils represents a clear opportunity for monitoring. However, several technological limitations will delay its routine use for quantifying a MDS of soil quality.

Soil NIR spectra can be used as an integrated measure of soil quality, so as to classify sites according to their global degradation status or for monitoring the effect of an ecological factor on soil quality. NIRS also opens a new way for soil quality assessment, as reliable quantification of particular soil functions, ecosystem services, or threats can be evaluated from a flight campaign or a simple NIR scanning of a soil sample. Implementing this specific approach to soil quality with laboratory and imaging NIRS will provide powerful tools to address the specific management goals of soil quality policies. Laboratory NIRS offers a low-cost solution for soil quality monitoring networks which could allow an increase in their spatial coverage and an increase in their sampling frequency. Imaging NIRS provides an interesting solution for the spatial assessment of some specific soil threats in environmentally sensitive areas.

An urgent research need is the development of international soil spectral libraries that will improve the predictive ability of NIRS for soil quality attributes whatever the soil type. Coupling NIR spectral libraries with other diffuse reflectance measurements of soils, such as mid-infrared reflectance spectra, will probably be the next step towards spectral sensing of soil quality worldwide. 


\section{Acknowledgements}

This review was initiated at the workshop "NIRS in Soil Science", 25-26 October 2007, Grenoble, France (http://spirsolgrenoble2007.free.fr/) organized by HélioSPIR and Cemagref Grenoble. The authors are grateful to $\mathrm{V}$. Bellon-Maurel, all participants of this workshop and three anonymous reviewers for their useful comments, and to S. De Danieli for its logistical help during the workshop. This work was supported by the French Agency for Environment and Energy Management (ADEME) and Cemagref.

\section{References}

Adamchuk, V.I., Hummel, J.W., Morgan, M.T. \& Upadhyaya, S.K. 2004. On-the-go soil sensors for precision agriculture. Computers and Electronics in Agriculture, 44, 71-91.

Al-Abbas, A.H., Swain, P.H. \& Baumgardner, M.F. 1972. Relating organic matter and clay content to the multispectral radiance of soils. Soil Science, 114, 477-485.

Albrecht, R., Joffre, R., Gros, R., Le Petit, J., Terrom, G. \& Périssol, C. 2008. Efficiency of nearinfrared reflectance spectroscopy to assess and predict the stage of transformation of organic matter in the composting process. Bioresource Technology, 99, 448-455.

Andrews, S.S., Karlen, D.L. \& Cambardella, C.A. 2004. The soil management assessment framework: a quantitative soil quality evaluation method. Soil Science Society of America Journal, 68, 1945-1962.

Aspinall, R.J., Marcus, W. \& Boardman, J. 2002. Considerations in collecting, processing and analysing high spatial resolution hyperspectral data for environmental investigations. Journal of Geographical Systems, 4, 15-29. 
Awiti, A.O., Walsh, M.G., Shepherd, K.D. \& Kinyamario, J. 2008. Soil condition classification using infrared spectroscopy: A proposition for assessment of soil condition along a tropical forestcropland chronosequence. Geoderma, 143, 73-84.

Barnes, E.W., Sudduth, K.A., Hummel, J.W., Lesch, S.M., Corwin, D.L., Yang, C., Daughtry, C.S.T. \& Bausch, W.C. 2003. Remote- and ground-based sensor techniques to map soil properties. Photogrammetric Engineering and Remote Sensing, 69, 619-630.

Bartholomeus, H., Epema, G. \& Schaepman, M. 2007. Determining iron content in Mediterranean soils in partly vegetated areas, using spectral reflectance and imaging spectroscopy. International Journal of Applied Earth Observation and Geoinformation, 9, 194-203.

Bartholomeus, H., Schaepman, M., Kooistra, L., Stevens, A., Hoogmoed, W. \& Spaargaren, O. 2008. Spectral reflectance based indices for soil organic carbon quantification. Geoderma, $145,28-36$.

Ben-Dor, E. \& Banin, A. 1995a. Near-infrared analysis as a rapid method to simultaneously evaluate several soil properties. Soil Science Society of America Journal, 59, 364-372.

Ben-Dor, E. \& Banin, A. 1995b. Quantitative analysis of convolved TM spectra of soils in the visible, near infrared and short-wave infrared spectral regions (0.4-2.5mm). International Journal of Remote Sensing, 18, 3509-3528.

Ben-Dor, E., Patkin, K., Banin, A. \& Karnieli, A. 2002. Mapping of several soil properties using DAIS-7915 hyperspectral scanner data - a case study over clayey soils in Israel. International Journal of Remote Sensing, 23, 1043-1062.

Ben-Dor, E., Kindel, B. \& Goetz, A.F.H. 2004. Quality assessment of several methods to recover surface reflectance using synthetic imaging spectroscopy data. Remote Sensing of Environment, 90, 389-404.

Ben-Dor, E., Taylor, R.G., Hill, J., Demattê, J.A.M., Whiting, M.L., Chabrillat, S. \& Sommer, S. 2008a. Imaging spectrometry for soil applications. In: Advances in Agronomy, volume 97 (ed. D.L. Sparks), pp. 321-392. Academic Press, Elsevier. 
Ben-Dor, E., Heller, D. \& Cudnovsky, A. 2008b. A novel method of classifying soil profiles in the field using optical means. Soil Science Society of America Journal, 72, 1113-1123.

Bengtsson, S., Berglöf, T. \& Kylin, H. 2007. Near infrared reflectance spectroscopy as a tool to predict pesticide sorption in soil. Bulletin of Environmental Contamination and Toxicology, 78, 295-298.

Biasioli, M., Barberis, R. \& Ajmone-Marsan, F. 2005. The influence of a large city on some soil properties and metals content. Science of the Total Environment, 356, 154-164.

Bogrekci, I. \& Lee, W.S. 2005. Improving phosphorus sensing by eliminating soil particle size effect in spectral measurement. Transactions of the ASAE, 48, 1971-1978.

Bowers, S.A. \& Hanks, R.J. 1965. Reflection of radiant energy from soils. Soil Science, 100, 130138.

Breure, A.M. 2004. Ecological soil monitoring and soil quality assessment. In: Vital Soil: Function, Value, and Properties (eds. P. Doelman \& H. Eijsackers), pp. 281-306. Developments in Soil Science, 29. Elsevier, Amsterdam.

Brown, D.J., Shepherd, K.D., Walsh, M.G., Dewayne Mays, M. \& Reinsch, T.G. 2006. Global soil characterization with VNIR diffuse reflectance spectroscopy. Geoderma, 132, 273-290.

Brunet, D., Barthès, B.G., Chotte, J.L. \& Feller, C. 2007. Determination of carbon and nitrogen contents in Alfisols, Oxisols and Ultisols from Africa and Brazil using NIRS analysis: Effects of sample grinding and set heterogeneity. Geoderma, 139, 106-117.

Burns, D.A. \& Ciurczack, E.W. 2001. Handbook of Near-Infrared Analysis. Marcel Dekker, New York.

Cécillon, L., Cassagne, N., Czarnes, S., Gros, R. \& Brun, J.J. 2008. Variable selection in near infrared spectra for the biological characterization of soil and earthworm casts. Soil Biology \& Biochemistry, 40, 1975-1979. 
Cécillon, L., Cassagne, N., Czarnes, S., Gros, R., Vennetier, M. \& Brun, J.J. 2009. Predicting soil quality indices with near infrared analysis in a wildfire chronosequence. Science of the Total Environment, 407, 1200-1205.

Cen, H. \& He, Y. 2007. Theory and application of near infrared reflectance spectroscopy in determination of food quality. Trends in Food Science \& Technology, 18, 72-83.

Chabrillat, S., Goetz, A.F.H., Krosley, L. \& Olsen , H.W. 2002. Use of hyperspectral images in the identification and mapping of expansive clay soils and the role of spatial resolution. Remote Sensing of Environment, 82, 431-445.

Chang, C.W., Laird, D.A., Mausbach, M.J. \& Hurburgh, C.R.J. 2001. Near-infrared reflectance spectroscopy - Principal components regression analyses of soil properties. Soil Science Society of America Journal, 65, 480-490.

Chen, F., Kissel, D.E., West, L.T. \& Adkins, W. 2000. Field-scale mapping of surface soil organic carbon using remotely sensed imagery. Soil Science Society America Journal, 64, 746-753.

Cho, R.K., Lin G. \& Kwon, Y.K. 1998. Nondestructive analysis for nitrogens of soils by near infrared reflectance spectroscopy. Journal of Near Infrared Spectroscopy, 6, A87-A91.

Cierniewki, J. \& Courault, D. 1993. Bidirectional reflectance of bare soil surfaces in the visible and near-infrared range. Remote Sensing Reviews, 7, 321-339.

Ciurczack, E.W. 2001. Principles of near infrared spectroscopy. In: Handbook of Near-Infrared Analysis (eds. Burns, D.A. \& Ciurczack, E.W.), pp. 7-18. Marcel Dekker, New-York.

Cohen, M.J., Prenger, J.P. \& DeBusk, W.F. 2005a. Visible-near infrared spectroscopy for rapid, non-destructive assessment of wetland soil quality. Journal of Environmental Quality, 34, 1422-1434.

Cohen, M.J., Shepherd, K.D. \& Walsh, M.G. 2005b. Empirical reformulation of the universal soil loss equation for erosion risk assessment in a tropical watershed. Geoderma, 124, 235-252. 
Cohen, M.J., Dabral, S., Graham, W.D., Prenger, J.P. \& DeBusk, W.F. 2006. Evaluating ecological condition using soil biogeochemical parameters and near infrared reflectance spectra. Environmental Monitoring and Assessment, 116, 427-457.

Confalonieri, M., Fornasier, F., Ursino, A., Boccardi, F., Pintus, B. \& Odoardi, M. 2001. The potential of near infrared reflectance spectroscopy as a tool for the chemical characterisation of agricultural soils. Journal of Near Infrared Spectroscopy, 9, 123-131.

Dalal, R.C. \& Henry, R.J. 1986. Simultaneous determination of moisture, organic carbon, and total nitrogen by near infrared reflectance spectrophotometry. Soil Science Society of America Journal, 50, 120-123.

Demattê, J.A.M., Sousa, A.A., Alves, M.C., Nanni, M.R., Fiorio, P.R. \& Campos, R.C. 2006. Determining soil water status and other soil characteristics by spectral proximal sensing. Geoderma, 135, 179-195.

De Tar, W.R., Chesson, J.H., Penner, J.V. \& Ojala, J.C. 2008. Detection of soil properties with airborne hyperspectral measurements of bare fields. Transactions of the ASABE, 51, 463-470.

Doelman, P. \& Eijsackers, H. 2004. Vital Soil: Function, Value, and Properties. Developments in Soil Science, 29. Elsevier, Amsterdam.

Doran, J.W. \& Parkin, T.B. 1994. Defining and assessing soil quality. In: Defining Soil Quality for a Sustainable Environment (eds. J.W. Doran, D.C. Coleman, D.F. Bzedicek \& B.A. Steward), pp. 3-21. Soil Science Society of America Special Publication 35, Madison, WI, USA.

Doran, J.W. \& Safley, M. 1997. Defining and assessing soil health and sustainable productivity. In: Biological Indicators of Soil Health (eds. C.E. Pankhurst, B.M. Doube \& V.V.S.R. Gupta), pp. 128. CAB International, Wallingford, UK.

Dunn, B.W., Batten, G.D., Beecher, H.G. \& Ciavarella, S. 2002. The potential of near-infrared reflectance spectroscopy for soil analysis - a case study from the Riverine Plain of southeastern Australia. Australian Journal of Experimental Agriculture, 42, 607-614. 
Eijsackers, H. 2004. Leading concepts towards vital soil. In: Vital Soil: Function, Value, and Properties (eds. P. Doelman \& H. Eijsackers), pp. 1-20. Developments in Soil Science, 29. Elsevier, Amsterdam.

European Commission 2006. Communication from the Commission to the Council, the European Parliament, the European Economic and Social Committee and the Committee of the Regions: Thematic Strategy for Soil Protection. COM (2006)231 final, Brussels. (At: http://ec.europa.eu/environment/soil/pdf/com 20060231 en.pdf. Accessed: 14/05/2008)

Farifteh, J., van der Meer, F., van der Meijde, M. \& Atzberger, C. 2008. Spectral characteristics of salt-affected soils: A laboratory experiment. Geoderma, 145, 196-206.

Fernández Pierna, J.A. \& Dardenne, P. 2008. Soil parameter quantification by NIRS as a Chemometric challenge at 'Chimiométrie 2006'. Chemometrics and Intelligent Laboratory Systems, 91, 94-98.

Fystro, G. 2002. The prediction of $\mathrm{C}$ and $\mathrm{N}$ content and their potential mineralisation in heterogeneous soil samples using Vis-NIR spectroscopy and comparative methods. Plant and Soil, 246, 139-149.

Gaffey, S.J. \& Reed, K.L. 1987. Copper in calcite: detection by visible and near-infrared reflectance. Economic Geology, 82, 195-200.

Galvão, L.S., Pizarro, M.A. \& Neves Epiphanio, J.C. 2001. Variations in reflectance of tropical soils: spectral-chemical composition relationships from AVIRIS data. Remote Sensing and Environment, 75, 245-255.

Geladi, P. 2003. Chemometrics in spectroscopy. Part 1. Classical chemometrics. Spectrochimica Acta Part B, 58, 767-782.

Genot, V., Colinet, G., Dardenne, P., Bah, B., Legrain, X. \& Bock, L. 2007. Etude de la performance de la spectroscopie proche infrarouge pour la mesure de caractéristiques du sol nécessaires au conseil de fumure. (In French). In: Actes des $9^{\text {èmes }}$ Journées Nationales de l'Etude des Sols, 3-5 April 2007, Angers, France, pp. 379-380. AFES, Orléans, France. 
Goldshleger, N., Ben-Dor, E., Benyamini, Y., Agassi, M. \& Blumberg, D. 2001. Characterization of soil's structural crust by spectral reflectance in the SWIR region (1.2-2.5 $\mu \mathrm{m})$. Terra Nova, 13, 12-17.

Goldshleger, N., Ben-Dor, E., Benyamini, Y., Blumberg, D. \& Agassi, M. 2002. Spectral properties and hydraulic conductance of soil crusts formed by raindrop impact. International Journal of Remote Sensing, 23, 3909-3920.

Gomez, C., Viscarra Rossel, R.A. \& McBratney, A.B. 2008. Soil organic carbon prediction by hyperspectral remote sensing and field vis-NIR spectroscopy: an Australian case study. Geoderma, 146, 403-411.

Guerrero, C., Mataix-Solera, J., Arcenegui, V., Mataix-Beneyto, J. \& Gómez, I. 2007. Near-infrared spectroscopy to estimate the maximum temperatures reached on burned soils. Soil Science Society of America Journal, 71, 1029-1037.

Haberern, J. 1992. Viewpoint: A soil health index. Journal of Soil and Water Conservation, 47, 6.

Hedde, M., Lavelle, P., Joffre, R., Jiménez, J.J. \& Decaëns, T. 2005. Specific functional signature in soil macro-invertebrates biostructures. Functional Ecology, 19, 785-793.

Henderson, T.L., Baumgardner, M.F., Franzmeier, D.P., Stott, D.E. \& Coster D.C. 1992. High dimensional reflectance analysis of soil organic matter. Soil Science Society of America Journal, 56, 865-872.

Islam, K., Singh, B. \& McBratney, A. 2003. Simultaneous estimation of several soil properties by ultra-violet, visible, and near-infrared reflectance spectroscopy. Australian Journal of Soil Research, 41, 1101-1114.

Jolivet, C., Boulonne, L. \& Ratié, C. 2006. Manuel du Réseau de Mesures de la Qualité des Sols, Edition 2006. Unité Infosol, INRA Orléans, France.

Kooistra, L., Wehrens, R., Leuven, R.S.E.W. \& Buydens, L.M.C. 2001. Possibilities of visible-nearinfrared spectroscopy for the assessment of soil contamination in river floodplains. Analytica Chimica Acta, 446, 97-105. 
Kooistra, L., Wanders, J., Epema, G.F., Leuven, R.S.E.W., Wehrens, R. \& Buydens,

L.M.C. 2003. The potential of field spectroscopy for the assessment of sediment properties in river floodplains. Analytica Chimica Acta, 484, 198-200.

Lagacherie, P., Baret, F., Feret, J.-B., Madeira Netto, J. \& Robbez-Masson, J.-M. 2008. Estimation of soil clay and calcium carbonate using laboratory, field and airborne hyperspectral measurements. Remote Sensing of Environment, 112, 825-835.

Larson, W.E. \& Pierce, F.J. 1991. Conservation and enhancement of soil quality. In: Evaluation for Sustainable Land Management in the Developing World. Vol. 2, pp. 175-203. ISBRAM Proc. 12 (2), International Board for Soil Research and Management, Bangkok, Thailand.

Lavelle, P., Decaëns, T., Aubert, M., Barot, S., Blouin, M., Bureau, F., Margerie, P., Mora, P. \& Rossi, J.P. 2006. Soil invertebrates and ecosystem services. European Journal of Soil Biology, 42, S3-S15.

Ludwig, B., Khanna, P.K., Bauhus, J. \& Hopmans, P. 2002. Near infrared spectroscopy of forest soils to determine chemical and biological properties related to soil sustainability. Forest Ecology and Management, 171, 121-132.

Malley, D.F., Yesmin, L. \& Eilers, R.G. 2002. Rapid analysis of hog manure and manure-amended soils using near-infrared spectroscopy. Soil Science Society of America Journal, 66, 16771686.

Malley, D.F., Martin, P.D. \& Ben-Dor, E. 2004. Application in analysis of soils. In: Near-Infrared Spectroscopy in Agriculture (ed. C.A. Roberts), pp. 729-784. Agronomy Monograph 44. American Society of Agronomy, Crop Science Society of America, Soil Science Society of America, Madison, WI, USA.

Martens, H.A. \& Dardenne, P. 1998. Validation and verification of regression in small data sets. Chemometrics and intelligent laboratory systems, 44, 99-121.

Marx, B.D. \& Eilers, H.C. 2002. Multivariate calibration stability: a comparison of methods. Journal of Chemometrics, 16, 129-140. 
McBratney, A.B., Minasny, B. \& Viscarra Rossel, R. 2006. Spectral soil analysis and inference systems: A powerful combination for solving the soil data crisis. Geoderma, 136, 272-278.

Morón, A. \& Cozzolino, D. 2003. Exploring the use of near infrared reflectance spectroscopy to study physical properties and microelements in soils. Journal of Near Infrared Spectroscopy, $11,145-154$.

Morra, M.J., Hall, M.H.\& Freeborn, L.L. 1991. Carbon and nitrogen analysis of soil fractions using near-infrared reflectance spectroscopy. Soil Science Society of America Journal, 55, 288-291.

Morvan, X., Saby, N.P.A., Arrouays, D., Le Bas, C., Jones, R.J.A., Verheijen, F.G.A., Bellamy, P.H., Stephens, M. \& Kibblewhite, M.G. 2008. Soil monitoring in Europe: A review of existing systems and requirements for harmonisation. Science of the Total Environment, 391, 1-12.

Mouazen, A.M., Maleki, M.R., De Baerdemaeker, J. \& Ramon, H. 2007. On-line measurement of some selected soil properties using a VIS-NIR sensor. Soil \& Tillage Research, 93, 13-27.

Murray, I. \& Williams, P.C. 1990. Chemical principles of near-infrared technology. In: Near-Infrared Technology in the Agricultural and Food Industries (eds. P. Williams \& K. Norris), pp. 17-34. American Association of Cereal Chemists, St Paul, MN, USA.

Mutuo, P.K., Shepherd, K.D., Albrecht, A. \& Cadisch, G. 2006. Prediction of carbon mineralization rates from different soil physical fractions using diffuse reflectance spectroscopy. Soil Biology \& Biochemistry, 38, 1658-1664.

Nanni, M.R. \& Demattê, J.A.M. 2006. Spectral reflectance methodology in comparison to traditional soil analysis. Soil Science Society of America Journal, 70, 393-407.

Odlare, M., Svensson, K. \& Pell, M. 2005. Near infrared reflectance spectroscopy for assessment of spatial soil variation in an agricultural field Geoderma, 126, 193-202.

Palmborg, C. \& Nordgren, A. 1993. Modelling microbial activity and biomass in forest soil with substrate quality measured using near infrared reflectance spectroscopy. Soil Biology \& Biochemistry, 25, 1713-1718. 
Patzold, S., Mertens, F. M., Bornemann, L., Koleczek, B., Franke, J., Feilhauer, H. \& Welp, G. 2008. Soil heterogeneity at the field scale: a challenge for precision crop protection. Precision Agriculture, 9, 367-390.

Reeves III, J.B. \& McCarty, G.W. 2001. Quantitative analysis of agricultural soils using near infrared reflectance spectroscopy and a fibre-optic probe. Journal of Near Infrared Spectroscopy, 9, 25-34.

Reeves III, J.B., McCarty, G.W. \& Meisinger J.J. 1999. Near infrared reflectance spectroscopy for the analysis of agricultural soils. Journal of Near Infrared Spectroscopy, 7, 179-193.

Reeves III, J.B., McCarty, G.W. \& Meisinger, J.J. 2000. Near infrared reflectance spectroscopy for the determination of biological activity in agricultural soils. Journal of Near Infrared Spectroscopy, 8, 161-170.

Rinnan, R. \& Rinnan, A. 2007. Application of near infrared reflectance (NIR) and fluorescence spectroscopy to analysis of microbiological and chemical properties of arctic soil. Soil Biology \& Biochemistry, 39, 1664-1673.

Salgó, A., Nagy, J., Tarnóy, J., Marth, P., Pálmai O. \& Szabó-Kele, G. 1998. Characterisation of soils by the near infrared technique. Journal of Near Infrared Spectroscopy, 6, 199-203.

Selige, T., Böhner, J. \& Schmidhalter, U. 2006. High resolution topsoil mapping using hyperspectral image and field data in multivariate regression modelling procedures. Geoderma, 136, 235-244.

Shenk, J.S., Westerhaus, M.O. \& Templeton Jr., W.C. 1985. Calibration transfer between near infrared reflectance spectrophotometers. Crop Science, 25, 159-161.

Shenk, J.S., Westerhaus, M.O. \& Berzaghi, P. 1997. Investigation of a LOCAL calibration procedure for near infrared instruments. Journal of Near Infrared Spectroscopy, 5, 223-232.

Shepherd, K.D. \& Walsh, M.G. 2002. Development of reflectance spectral libraries for characterization of soil properties. Soil Science Society of America Journal, 66, 988-998. 
Shepherd, K.D. \& Walsh, M.G. 2007. Review: Infrared spectroscopy - enabling an evidencebased diagnostic surveillance approach to agricultural and environmental management in developing countries. Journal of Near Infrared Spectroscopy, 15, 1-19.

Sheppard, N., Willis, H.A. \& Rigg, J.C. 1985. International Union of Pure and Applied Chemistry (IUPAC). Names, symbols, definitions, and units of quantities in optical spectroscopy (Recommendations 1984). Pure \& Applied Chemistry, 57, 105-120.

Shonk, J.L., Gaultney, L.D., Schulze, D.G. \& van Scoyoc, G.E. 1991. Spectroscopic sensing of soil organic matter. Transactions of the ASAE, 34, 1978-1984.

Sojka, R.E. \& Upchurch, D.R. 1999. Reservations regarding the soil quality concept. Soil Science Society of America Journal, 63, 1039-1054.

Stevens, A., van Wesemael, B., Bartholomeus, H., Rosillon, D., Tychon, B. \& Ben-Dor, E. 2008. Laboratory, field and airborne spectroscopy for monitoring organic carbon content in agricultural soils. Geoderma, 144, 395-404.

Stoner, E. R. \& Baumgardner, M. F. 1981. Characteristic variations in reflectance of surface soils. Soil Science Society of America Journal, 45, 1161-1165.

Sudduth, K.A. \& Hummel, J.W. 1993. Soil organic matter, CEC, and moisture sensing with a portable NIR spectrophotometer. Transactions of the ASAE, 36, 1571-1582.

Tenenhaus, M. 1998. La Régression PLS. Editions Technip, Paris.

Terhoeven-Urselmans, T., Schmidt, H., Joergensen, R.G. \& Ludwig, B. 2008. Usefulness of nearinfrared spectroscopy to determine biological and chemical soil properties: Importance of sample pre-treatment. Soil Biology \& Biochemistry, 40, 1178-1188.

Udelhoven, T., Emmerling, C. \& Jarmer, T. 2003. Quantitative analysis of soil chemical properties with diffuse reflectance spectrometry and partial least-square regression: a feasibility study. Plant and Soil, 251, 319-329. 
Vågen T-G., Shepherd K.D. \&Walsh M.G. 2006. Sensing landscape level change in soil quality following deforestation and conversion in the highlands of Madagascar using Vis-NIR spectroscopy. Geoderma, 133, 281-294.

Velasquez, E., Lavelle, P., Barrios, E., Joffre, R. \& Reversat, F. 2005. Evaluating soil quality in tropical agroecosystems of Colombia using NIRS. Soil Biology \& Biochemistry, 37, 889-898.

Velasquez, E., Lavelle, P. \& Andrade, M. 2007. GISQ, a multifunctional indicator of soil quality. Soil Biology \& Biochemistry, 39, 3066-3080.

Viscarra Rossel, R.A. 2008. The Soil Spectroscopy Group and the development of a global spectral library. In: $3^{\text {rd }}$ Global Workshop on Digital Soil Mapping, 30 September - 3 October 2008, Utah State University, Logan, Utah, USA.

Viscarra Rossel, R.A. \& McBratney, A.B. 1998. Laboratory evaluation of a proximal sensing technique for simultaneous measurement of soil clay and water content. Geoderma, 85, 19-39.

Viscarra Rossel, R.A., Walvoort, D.J.J., McBratney, A.B., Janik L.J. \& Skjemstad, J.O. 2006. Visible, near-infrared, mid-infrared or combined diffuse reflectance spectroscopy for simultaneous assessment of various soil properties. Geoderma, 131, 59-75.

Wander, M.M. \& Drinkwater, L.E. 2000. Fostering soil stewardship through soil quality assessment. Applied Soil Ecology, 15, 61-73.

Weng, Y. L., Gong, P. \& Zhu, Z. L. 2008. Soil salt content estimation in the Yellow River delta with satellite hyperspectral data. Canadian Journal of Remote Sensing, 34, 259-270.

Wetzel, D.L. 1983. Near-infrared reflectance analysis. Sleeper among spectroscopic techniques. Analytical Chemistry, 55, 1165 A-1176 A.

Williams, P.C. 1993. What does the raw material have to say? NIR news, 5, 13.

Wu, Y., Chen, J., Ji, J., Gong, P., Liao, Q., Tian, Q. \& Ma, H. 2007. A mechanism study of reflectance spectroscopy for investigating heavy metals in soils. Soil Science Society of America Journal, 71, 918-926. 
Zornoza, R., Mataix-Solera, J., Guerrero, C., Arcenegui, V., García-Orenes, F., Mataix-Beneyto, J. \& Morugán, A. 2007. Evaluation of soil quality using multiple linear regression based on physical, chemical and biochemical properties. Science of the Total Environment, 378, 233237.

Zornoza, R., Guerrero, C., Mataix-Solera, J., Scow, K.M., Arcenegui, V. \& Mataix-Beneyto, J. 2008. Near infrared spectroscopy for determination of various physical, chemical and biochemical properties in Mediterranean soils. Soil Biology \& Biochemistry, 40, 1923-1930. 


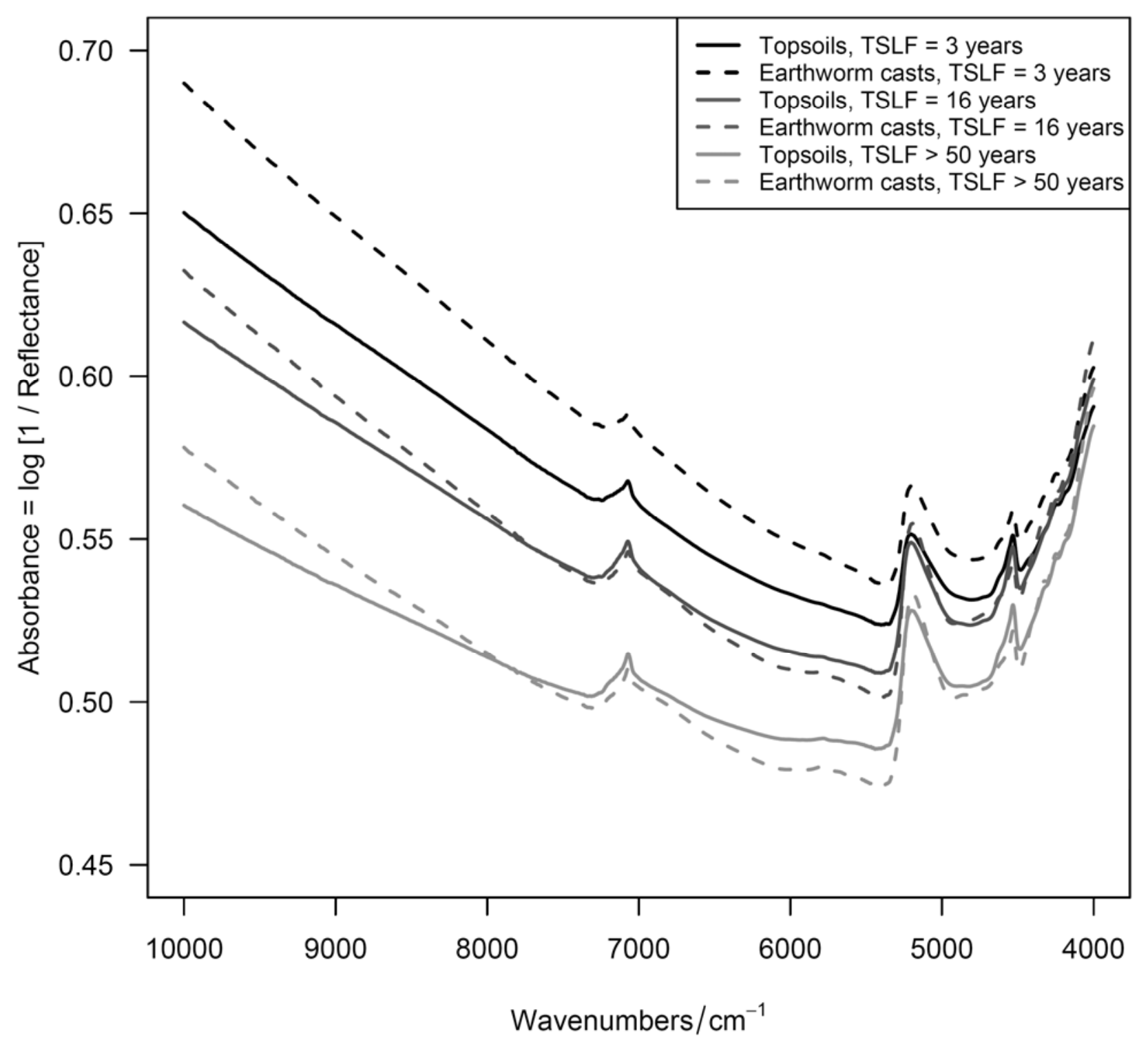

Figure 1 Weak absorption peaks in NIR spectra of topsoils $(0-5 \mathrm{~cm})$ and earthworm casts collected in French Mediterranean areas affected by wildfire (Cécillon et al., 2009). Each spectrum is an average of samples originating from five to ten plots.

Wavelengths $(\mathrm{nm})$ can be computed from wavenumbers $\left(\mathrm{cm}^{-1}\right)$ with the following formula:

Wavelength $=[1 /$ Wavenumber $] \times 10^{7}$

Abbreviation: TSLF $=$ time since last fire 

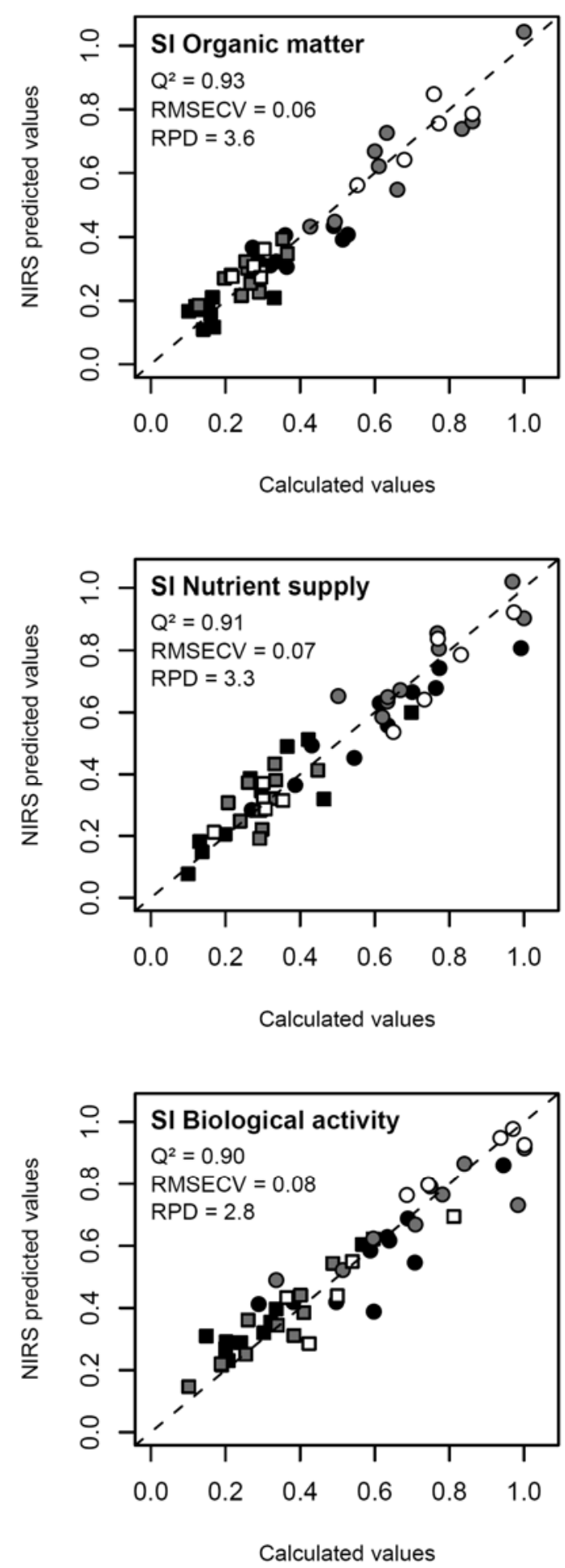

Figure 2 Predictive efficiency of laboratory NIRS for specific indices (SI) of soil quality related to three soil ecosystem services in French Mediterranean areas (modified from Cécillon et al., 2009). Squares correspond to topsoil samples and circles to earthworm casts. Black, grey and white symbols correspond to sites where time since last fire was 3, 16 and $>50$ years, respectively. The dashed lines represent the 1:1 lines.

Abbreviations: $\mathrm{Q}^{2}=$ cross-validated $\mathrm{R}^{2} ; \mathrm{RMSECV}=$ root mean squared error of cross-validation RPD = ratio of performance-to-deviation (calculated as RPD = SD RMSECV ${ }^{-1}$ ); SD = standard deviation of calculated SIs 


\section{TABLES}

Table 1a Predictive efficiency of NIRS for MDS regarding soil chemical variables and associated soil functions, ecosystem services or threats.

\begin{tabular}{|c|c|c|c|c|c|}
\hline $\begin{array}{l}\text { MDS } \\
\text { variable }^{1}\end{array}$ & $\begin{array}{c}\text { Soil } \\
\text { functions }\end{array}$ & $\begin{array}{c}\text { Soil } \\
\text { ecosystem } \\
\text { services }^{3}\end{array}$ & $\begin{array}{c}\text { Soil threats } \\
\text { studied in } \mathrm{SMN}^{4}\end{array}$ & $\begin{array}{l}\text { NIRS } \\
\text { predictive } \\
\text { efficiency }\end{array}$ & Associated NIR wavelengths and references \\
\hline Organic C & $\begin{array}{l}\text { Nutr. Cycling } \\
\text { filter-buffer; }^{6} \\
\text { biodiv-habitat }^{7}\end{array}$ & $\begin{array}{l}\text { Nutr. Cycling } \\
\text { climate }^{6} \\
\text { detox }^{9}\end{array}$ & SOM $^{10}$ decline & Good & $\begin{array}{l}\text { 1744, 1870, } 2052 \text { nm (Dalal \& Henry, 1986); 1955-1965, 2215, } \\
\text { 2265, 2285-2295, 2315-2495 nm (Henderson et al., 1992); } \\
\text { 2218, 2350 nm (Salgó et al., 1998); } 2200 \text { nm (Confalonieri et al., } \\
\text { 2001); 1109, 1232, 1414, 1522 nm (Mouazen et al., 2007); } \\
\text { 1420, 1900-1950, 2040-2260, 2440-2460 nm (Rinnan \& Rinnan, } \\
\text { 2007); 1130, 2410 nm (Terhoeven-Urselmans et al., 2008) }\end{array}$ \\
\hline $\begin{array}{l}\text { Total and } \\
\text { organic N }\end{array}$ & $\begin{array}{l}\text { Nutr. Cycling } \\
\text { filter-buffer; } \\
\text { biodiv-habitat }^{7}\end{array}$ & $\begin{array}{l}\text { Nutr. Cycling } \\
\text { climate regul }^{8} \\
\text { detox }^{9}\end{array}$ & SOM $^{10}$ decline & Good & $\begin{array}{l}\text { For total N: 1702, 1870, } 2052 \text { nm (Dalal \& Henry, 1986); 1726, } \\
\text { 1826, } 2038 \text { nm (Morra et al., 1991) }\end{array}$ \\
\hline $\mathrm{PH}$ & $\begin{array}{l}\text { Nutr. Cycling } \\
\text { filter-buffer; } \\
\text { biodiv-habitat }^{7}\end{array}$ & Nutr. Cycling ${ }^{6}$ & Contamination & Mid & \\
\hline $\begin{array}{l}\text { Electrical } \\
\text { conductivity }\end{array}$ & Nutr. Cycling ${ }^{6}$ & Nutr. Cycling ${ }^{6}$ & $\begin{array}{l}\text { Desertification; } \\
\text { salinisation }\end{array}$ & Mid & \\
\hline $\begin{array}{l}\text { Mineral } \mathrm{N}, \mathrm{P} \text {, } \\
\mathrm{K}\end{array}$ & Nutr. Cycling ${ }^{6}$ & Nutr. Cycling ${ }^{6}$ & Contamination & Mid & $\begin{array}{l}\text { For } \mathrm{NH}_{4}: 1510-1650 \mathrm{~nm} \text { (Murray \& Williams, 1990); for total P: } \\
2021-2025,2081-2084 \text { nm (Bogrekci \& Lee, 2005); 2240- } \\
2400 \mathrm{~nm} \text { (Velasquez et al., 2005) }\end{array}$ \\
\hline $\begin{array}{l}\text { Heavy metal } \\
\text { content }\end{array}$ & $\begin{array}{l}\text { Nutr. Cycling } \\
\text { resilience; } \\
\text { filter-buffer }\end{array}$ & $\begin{array}{l}\text { Nutr. Cycling } \\
\text { detox }^{9}\end{array}$ & Contamination & Mid & $\begin{array}{l}\text { For Cu: ca. 900, 1300, } 1500 \mathrm{~nm} \text { (Gaffey \& Reed, 1987); for Cd } \\
\text { and Zn: 1050, 1400, 1850, 2150, 2280, 2400, } 2470 \mathrm{~nm} \text { (Kooistra } \\
\text { et al., 2001) }\end{array}$ \\
\hline Salt content & Nutr. Cycling ${ }^{6}$ & & $\begin{array}{l}\text { Desertification; } \\
\text { salinisation }\end{array}$ & Mid & $\begin{array}{l}\text { For } \mathrm{NaCl}: 1930 \mathrm{~nm} \text {; for } \mathrm{KCl}: 1430 \mathrm{~nm} \text {; for } \mathrm{MgSO}_{4}: 1480 \mathrm{~nm} \text {; for } \\
\mathrm{Na}_{2} \mathrm{SO}_{4}: 1825 \mathrm{~nm} \text {; for } \mathrm{MgCl}_{2}: 1925 \mathrm{~nm} \text { (Farifteh et al., 2008) }\end{array}$ \\
\hline
\end{tabular}

${ }^{1}$ modified from Doran \& Parkin, 1994; ${ }^{2}$ after Andrews et al., 2004; ${ }^{3}$ after Lavelle et al., 2006; ${ }^{4}$ after Morvan et al., 2008; ${ }^{5}$ based on validation statistics ( $\mathrm{R}^{2}$, standard error of prediction); ${ }^{6}$ nutrient cycling; ${ }^{7}$ biodiversity and habitat; ${ }^{8}$ climate regulation; ${ }^{9}$ detoxification; ${ }^{10}$ soil organic matter. 
Table 1b Predictive efficiency of NIRS for MDS regarding soil physical properties and associated soil functions, ecosystem services or threats.

\begin{tabular}{|c|c|c|c|c|c|}
\hline $\begin{array}{l}\text { MDS } \\
\text { variable }^{1}\end{array}$ & $\begin{array}{l}\text { Soil } \\
\text { functions }^{2}\end{array}$ & $\begin{array}{l}\text { Soil } \\
\text { ecosystem } \\
\text { services }^{3}\end{array}$ & $\begin{array}{l}\text { Soil threats } \\
\text { studied in } \\
\text { SMN }^{4}\end{array}$ & \begin{tabular}{|c|} 
NIRS \\
predictive \\
efficiency $^{5}$
\end{tabular} & Associated NIR wavelengths and references \\
\hline Soil loss & $\begin{array}{l}\text { Physical support; } \\
\text { water relations }\end{array}$ & Erosion control & Soil erosion & Poor & $\begin{array}{l}\text { For infiltration of crusted soils: ca. 1400, 1450, 1900, } 2200 \mathrm{~nm} \\
\text { (Goldshleger et al., 2001, 2002) }\end{array}$ \\
\hline WSA $^{6}$ & $\begin{array}{l}\text { Physical support; } \\
\text { water relations }\end{array}$ & $\begin{array}{l}\text { Erosion control; } \\
\text { climate regul }^{7}\end{array}$ & $\begin{array}{l}\text { Soil erosion; } \\
\text { SOM }^{8} \text { decline }\end{array}$ & Mid & \\
\hline $\begin{array}{l}\text { Soil } \\
\text { texture }\end{array}$ & $\begin{array}{l}\text { Physical support; } \\
\text { biodiv-habitat } \\
\text { filter-buffer }\end{array}$ & $\begin{array}{l}\text { Erosion control; } \\
\text { detox }^{10}\end{array}$ & $\begin{array}{l}\text { Compaction; } \\
\text { soil formation }\end{array}$ & Mid & $\begin{array}{l}\text { For clay: } 2200 \text { nm (Ben-Dor \& Banin, 1995a); } 1700 \text { nm (Viscarra } \\
\text { Rossel \& McBratney, 1998); 1901, } 1912 \text { nm (Islam et al., 2003); } \\
2206 \text { nm (Lagacherie et al., 2008); for particle size: 1323, 2021, } \\
2081 \text { nm (Bogrekci \& Lee, 2005) }\end{array}$ \\
\hline $\begin{array}{l}\text { Soil } \\
\text { structure }\end{array}$ & $\begin{array}{l}\text { Physical support; } \\
\text { biodiv-habitat } \\
\text {;ilter-buffer }\end{array}$ & $\begin{array}{l}\text { Erosion control; } \\
\text { climate regul; } \\
\text { water supply; } \\
\text { detox }^{10}\end{array}$ & $\begin{array}{l}\text { Compaction; } \\
\text { soil formation }\end{array}$ & Poor & For aggregate fractions: 1940, 2250 nm (Mutuo et al., 2006) \\
\hline $\begin{array}{l}\text { Depth of } \\
\text { soil and } \\
\text { rooting }\end{array}$ & $\begin{array}{l}\text { Physical support; } \\
\text { water relations; } \\
\text { biodiv-habitat }^{9}\end{array}$ & $\begin{array}{l}\text { Erosion control; } \\
\text { soil formation; } \\
\text { detox }^{10}\end{array}$ & Soil formation & Poor & \\
\hline $\begin{array}{l}\text { Bulk } \\
\text { density }\end{array}$ & $\begin{array}{l}\text { Physical support; } \\
\text { water relations }\end{array}$ & $\begin{array}{l}\text { Water supply; } \\
\text { soil formation }\end{array}$ & $\begin{array}{l}\text { Compaction; } \\
\text { SOM }^{8} \text { decline; } \\
\text { soil formation }\end{array}$ & Poor & \\
\hline $\mathrm{WHC}^{11}$ & $\begin{array}{l}\text { Physical support; } \\
\text { water relations }\end{array}$ & Water supply & & Mid & \\
\hline $\begin{array}{l}\text { Water } \\
\text { content }\end{array}$ & $\begin{array}{l}\text { Physical support; } \\
\text { water relations }\end{array}$ & Water supply & & Good & $\begin{array}{l}\text { 1400, 1900, } 2200 \text { nm (Bowers \& Hanks, 1965; Ben-Dor \& Banin, } \\
\text { 1995a; Demattê et al., 2006); 1926, 1954, 2150 nm (Dalal \& } \\
\text { Henry, 1986); 1450, } 1920 \text { nm (Salgó et al., 1998); 1450, 1950, } \\
2500 \text { nm (Viscarra Rossel \& McBratney, 1998); 1420, } 1920 \mathrm{~nm} \\
\text { (Confalonieri et al., 2001) }\end{array}$ \\
\hline $\begin{array}{l}\text { Soil } \\
\text { tempera- } \\
\text { ture }\end{array}$ & $\begin{array}{l}\text { Water relations; } \\
\text { nutr. Cycling }^{12} \text {; } \\
\text { biodiv-habitat }^{9}\end{array}$ & $\begin{array}{l}\text { Nutr. Cycling }{ }^{12} ; \\
\text { climate regul }^{7} ; \\
\text { soil formation }\end{array}$ & & Poor & \\
\hline
\end{tabular}


Table 1c Predictive efficiency of NIRS for MDS regarding soil biological properties and associated soil functions, ecosystem services or threats.

\begin{tabular}{|c|c|c|c|c|c|}
\hline MDS variable ${ }^{1}$ & Soil functions ${ }^{2}$ & $\begin{array}{l}\text { Soil ecosystem } \\
\text { services }^{3}\end{array}$ & $\begin{array}{l}\text { Soil threats } \\
\text { studied in } \\
\text { SMN }^{4}\end{array}$ & $\begin{array}{l}\text { NIRS } \\
\text { predictive } \\
\text { efficiency }\end{array}$ & Associated NIR wavelengths and references \\
\hline $\begin{array}{l}\text { Microbial } \\
\text { biomass }\end{array}$ & $\begin{array}{l}\text { Nutr. Cycling }{ }^{6} \text {; } \\
\text { resilience; filter- } \\
\text { buffer; biodiv- }^{\text {habitat }^{7}}\end{array}$ & $\begin{array}{l}\text { Nutr. Cycling } \\
\text { climate regul }^{6} ; \\
\text { soil formation; } \\
\text { plant production } \\
\text { and protection } \\
\end{array}$ & $\begin{array}{l}\text { Biodiversity } \\
\text { decline }\end{array}$ & Good & $\begin{array}{l}\text { 1408, 1842, } 2414 \mathrm{~nm} \text { (Terhoeven-Urselmans et al., } \\
\text { 2008); wavelength interval 1750-2500 nm (Cécillon } \\
\text { et al., 2008) }\end{array}$ \\
\hline Soil respiration & $\begin{array}{l}\text { Nutr. Cycling } \\
\text { resilience; filter- } \\
\text { buffer; biodiv- }^{\text {habitat }^{7}}\end{array}$ & $\begin{array}{l}\text { Nutr. Cycling } \\
\text { climate regul }^{8}\end{array}$ & $\begin{array}{l}\text { Biodiversity } \\
\text { decline }\end{array}$ & Good & $\begin{array}{l}800 \text { (Fe oxide effect), 2030, 2180, } 2200 \text { (clay } \\
\text { mineralogy effect), 2250, 2440, } 2460 \mathrm{~nm} \text { (Mutuo et } \\
\text { al., 2006); for basal respiration: 1836, } 2274 \mathrm{~nm} \text { (alkyl } \\
\text { groups), } 1510 \mathrm{~nm} \text { (amino groups) (Terhoeven- } \\
\text { Urselmans et al., 2008) }\end{array}$ \\
\hline $\begin{array}{l}\text { Potentially } \\
\text { mineralizable } \mathrm{N}\end{array}$ & $\begin{array}{l}\text { Nutr. Cycling }{ }^{6} ; \\
\text { resilience; filter- } \\
\text { buffer }\end{array}$ & Climate regul $^{8}$ & & Mid & \\
\hline $\begin{array}{l}\text { Cmic / Corg } \\
\text { ratio }\end{array}$ & $\begin{array}{l}\text { Nutr. Cycling } \\
\text { resilience; filter- } \\
\text { buffer; biodiv- }^{\text {habitat }^{7}} \\
\end{array}$ & & & Good & $\begin{array}{l}\text { Wavelength interval 1750-2500 nm (Cécillon et al., } \\
\text { 2008) }\end{array}$ \\
\hline $\begin{array}{l}\text { Respiration/ } \\
\text { biomass ratio }\end{array}$ & $\begin{array}{l}\text { Nutr. Cycling } \\
\text { resilience; filter- } \\
\text { buffer; biodiv- }^{\text {habitat }^{7}} \\
\end{array}$ & & & ND & \\
\hline Biodiversity & $\begin{array}{l}\text { Resilience; biodiv- } \\
\text { habitat }^{7}\end{array}$ & $\begin{array}{l}\text { Soil formation; } \\
\text { plant production } \\
\text { and protection }\end{array}$ & $\begin{array}{l}\text { Biodiversity } \\
\text { decline }\end{array}$ & Poor & \\
\hline
\end{tabular}

